\title{
Separation and Identification of Bovine Rumen Plant Lactobacillus
}

\author{
Zheng Xiaoliang, Wang Jihong, Li Yan, Huang Xiao, Cai Junwu, Wang Yu, Song Baifen
}

College of Life Sciences and Technology, Heilongjiang Bayi Agricultural University Heilongjiang Daqing 163319, China

DOI: $10.36347 /$ sjet.2020.v08i02.002

| Received: 12.02.2020 | Accepted: 21.02.2020 | Published: 25.02.2020

*Corresponding author: Song Baifen

Abstract

Original Research Article

The bovine rumen is main digestive site, but there exist complex variety of microorganisms, These microbial populations are generally influenced by the food supply, host genotype, health status, living environment, and the population effects of co-living microorganisms in the environment, which affects the utilization of feed and cattle health, so it is necessary to make clear bovine rumen microbial population. In this paper, a strain of bovine rumen lactic acid bacteria (Y-B-1) was isolated from adult bovine rumen by anaerobic isolation technique. By analyzing the morphology of bacteria, combining with sugar fermentation test, using biochemical identification tube to carry out physiological and biochemical tests of the strain. Finally, the homology analysis of 16S rRNA sequence was carried out. The results showed that the strain of Y-B-1 was Pediococcus pentosaceus. The biological characteristics of the strain were studied, and the optimum growth temperature was determined. The results showed that the strain grew best at $30^{\circ} \mathrm{C}$, pH $5.5 \mathrm{pH} 7.5$, and salt ion concentration below 7.5.

Keywords: Bovine Rumen, Separation, Identification, Physiological and Biochemical Analysis, 16S rRNA, Pediococcus pentosaceus.

Copyright @ 2020: This is an open-access article distributed under the terms of the Creative Commons Attribution license which permits unrestricted use, distribution, and reproduction in any medium for non-commercial use (NonCommercial, or CC-BY-NC) provided the original author and source are credited.

\section{INTRODUCTION}

The rumen is the main place for cattle to digest food. About $75 \%-80 \%$ of the dry matter collected was digested in the rumen, and more than $50 \%$ of the crude fiber was digested in the rumen [1]. Rumen digestion of feed is mainly the result of microbial interaction in the rumen. The rumen of cattle is home to complex and diverse microbiota, with species diversity and interaction complexity [2]. However, these microbial populations may vary depending on the type of diet fed by the animal, the living environment of the host and the population effect between symbiotic microorganisms in the environment [3]. How to improve the fermentation efficiency of rumen microorganisms and increase the fermentation subspecies of rumen bacteria is the main research method at present, which is to isolate and identify the microorganisms in the rumen and evaluate the physiological functions [4].

Spore-free gram-positive bacteria that produce large amounts of lactic acid from fermenting carbohydrates are collectively referred to as lactobacillus. A large number of studies have shown that lactic acid bacteria can regulate the normal flora of the gastrointestinal tract of the body and maintain the microecological balance, so as to produce effects on the nutritional state and physiological functions of the body [5]. At present, lactobacillus plantarum, lactobacillus bifidum, lactobacillus acidophilus and streptococcus faecalis are mainly used in feed additives [6]. In order to obtain lactic acid bacteria with better characteristics, this study isolated and identified lactic acid bacteria in bovine rumen and studied their biological characteristics.

\section{MATERIAL \\ SAMPLES AND MEDIUM}

The whole rumen of adult cattle was purchased from daqing agricultural wholesale market, jiuqu district, heilongjiang province. MRS medium and Agaragar were purchased from Beijing auboxing biotechnology co., LTD.

\section{The Other Major Reagent}

The complete set of lactic acid bacteria biochemical identification tube and other biochemical reagents were purchased from Qingdao haibo biological technology co., LTD.

\section{METHODS}

\section{Isolation and Purification of Strains}

The purchased intact adult bovine rumen was cut open with sterilized scissors under the condition of 
asepsis, the contents of the bovine rumen were discarded, and the samples were sampled in multiple inner layers. The samples were thoroughly mixed in sterile normal saline, and the supernatant was taken after resting for more than ten minutes. The supernatant was diluted in a series of proportions, and the diluent was evenly coated in the prepared MRS solid medium [7]. Anaerobic culture was conducted at a constant temperature of $37^{\circ} \mathrm{C}$ for $24 \mathrm{~h}$. The single colony with good growth was selected, and the strains were separated by stretting to obtain the pure culture. The morphology and staining characteristics of bacteria were observed by gram staining.

\section{Physiological and Biochemical Test}

Remove the complete set of lactic acid bacteria identification tube from the box, wipe and sterilize it with alcohol cotton. Fold it forcibly in the direction opposite to the easy folding point, then insert the folded tubule into the reagent rack, dip the inoculation needle into the purified culture of bacteria and inoculate into the open tubule, and seal the tubule with paraffin after inoculation. Placed it in $37 \pm 1^{\circ} \mathrm{C}$ incubator for culture, and 24-36 h to observe the identification tube color and gas production changes.

\section{PRIMER DESIGN}

On the basis of the dying characteristics and biochemical identification, it was preliminarily determined that the isolated bacteria belonged to the genus lactobacillus. According to the published rRNA gene sequence in Gen Bank, Primer Premier 5 software was used to design PCR to amplify the universal primers. The upstream Primer (F) sequence was 5'AGAGTTTGATCMTGGCTCAG-3', and the downstream Primer (R) sequence was 5'TACGGYTACCTTGTTACGAC TT-3. The primers were synthesized by jilin kumei biotechnology co. LTD.

\section{Extraction and PCR amplification of bacterial genome}

According to the instructions of the bacterial genome extraction kit, the bacterial genome was extracted as follows:

$1 \mathrm{~mL}$ of freshly cultured bacterial solution was placed in a clean centrifuge tube, and the precipitate was centrifuged. Solution A and lysozyme were added to lysozyme to lyse the bacteria, and protease $\mathrm{K}$ was added to degrade the protein, which was passed through the column and eluted to obtain genomic DNA.

The obtained bacterial DNA was used as the template and the designed $\mathrm{F}$ and $\mathrm{R}$ primers were used to amplify the $16 \mathrm{~S}$ rRNA gene of $y-b-1$ strain. The amplified PCR product was purified and sequenced by jilin kumei biotechnology co., LTD.

\section{$16 S$ rRNA Sequence Analysis}

The homology of the sequencing results was compared with those of lactic acid bacteria of the same and different genera in Gen Bank by BLAST software.

\section{Analysis of Strain Growth Characteristics Determination of Optimum Growth Temperature of Strain}

The isolated and purified single colony was inoculated into MRS liquid medium for overnight culture, and then was inoculated into the new MRS liquid medium with $2 \%$ inoculum. The bacteria were placed at $16^{\circ} \mathrm{C}, 23^{\circ} \mathrm{C}, 30^{\circ} \mathrm{C}, 37^{\circ} \mathrm{C}, 44^{\circ} \mathrm{C}, 51^{\circ} \mathrm{C}$ and $58^{\circ} \mathrm{C}$, respectively, for anaerobic culture. The OD600 value of the bacterial liquid was determined $24 \mathrm{~h}$ later and the curve was drawn.

\section{Determination of Strain Growth Curve}

After purification, pick a single colony vaccination to MRS liquid medium, $30^{\circ} \mathrm{C}$ under anaerobic conditions for the night, and then use liquid move from 100 (including 1 microbial inoculation to 5 $\mathrm{mL}$ new MRS liquid medium, $30^{\circ} \mathrm{C}$ anaerobic conditions continue to develop, sampling once every 2 $\mathrm{h}$, shake to determine microbial OD600 value, draw the bacteria growth curve after $24 \mathrm{~h}$.

\section{The acid resistance of the strain was determined}

The purified bacterial solution was inoculated into MRS liquid medium with initial $\mathrm{pH}$ of $\mathrm{pH} 1.5, \mathrm{pH}$ $3.5, \mathrm{pH} 5.5, \mathrm{pH} 7.5, \mathrm{pH} 9.5$ and $\mathrm{pH} 11.5$, respectively. After anaerobic culture at $30^{\circ} \mathrm{C}$ for $24 \mathrm{~h}$, the OD600 value of bacterial solution of different $\mathrm{pH}$ was shaken and sampled to determine the optimal $\mathrm{pH}$ value of the strain.

\section{The Salt Tolerance of the Strain Was Determined}

According to the above proportion, the purified bacterial liquid was inoculated into MRS liquid medium with concentration of $1.5 \%, 3.5 \%, 5.5 \%, 7.5 \%$, $9.5 \%$ and $11.5 \% \mathrm{NaCl}$, respectively. After anaerobic culture at $30^{\circ} \mathrm{C}$ for $24 \mathrm{~h}$, the OD600 value of bacterial liquid of different $\mathrm{pH}$ was shaken and sampled to determine the optimal salt concentration of bacterial strain.

\section{RESULT \\ Observation of Colony and Body Morphology}

Strains were isolated from bovine rumen and cultured using MRS solid medium under anaerobic conditions for $24 \mathrm{~h}$. It could be seen that the colony of y-b-1 strain was milky white with smooth surface and protruding on the surface of the medium. The colony size was different and opaque, with a diameter of $1 \sim 2$ mm (Figure-1 and Table-1). 

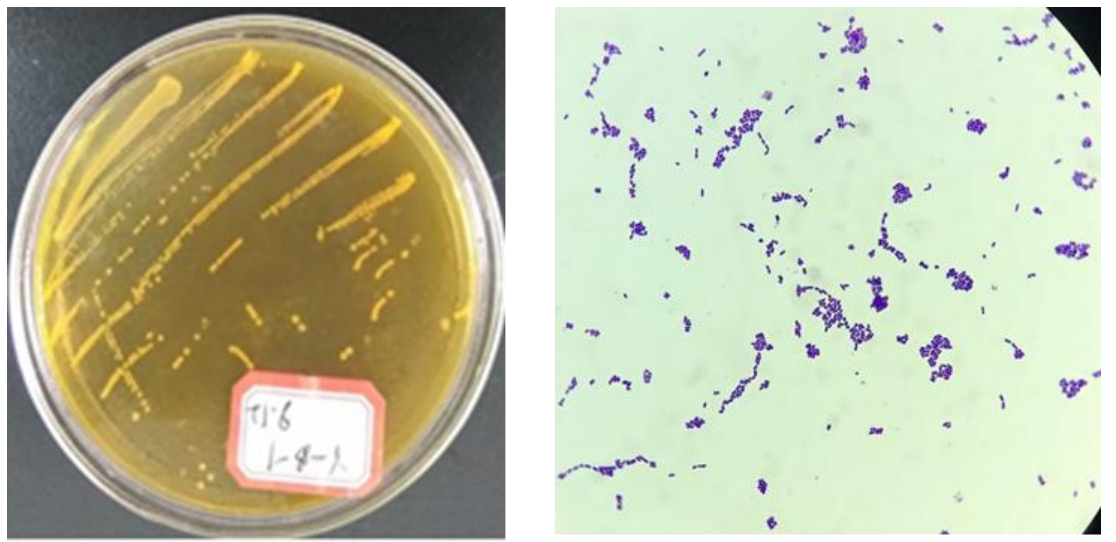

Fig-1: y-b-1 colony and oil mirror

Table-1: Gram staining and morphological observation of colony morphology

\begin{tabular}{|c|c|l|l|}
\hline Strain & $\begin{array}{c}\text { Gram } \\
\text { staining }\end{array}$ & \multicolumn{1}{c|}{ Colony characteristics } & \multicolumn{1}{c|}{ Colony morphology } \\
\hline Y-B-1 & G+ & $\begin{array}{l}\text { The growth rate was fast on MRS plate, and the } \\
\text { colonies were milky white, smooth and round on the } \\
\text { surface, protruding on the surface of the medium. The } \\
\text { colonies varied in size, with neat edges and opaque } \\
\text { edges. The diameter was 1 2 mm. }\end{array}$ & $\begin{array}{l}\text { The growth along the puncture line } \\
\text { of the vegetable was round like a } \\
\text { filamentous cell or round with } \\
\text { obtuse at both ends, without spores } \\
\text { or flagella. }\end{array}$ \\
\hline
\end{tabular}

\section{Sugar Fermentation Test}

Single colonies were selected and inoculated into the biochemical tube, sealed with sealing membrane, and incubated at $37^{\circ} \mathrm{C}$ for $36 \mathrm{~h}$. The results were obtained by comparing colors. According to the sugar fermentation test, this strain can ferment heptanoside, fibredisaccharide, maltose, mannitol, salicylate, sorbitol, sucrose, raffinose, inulin, lactose and $1 \%$ sodium hippuric acid (Table-2).

Table-2: Physiological and biochemical identification results of the strain

\begin{tabular}{|c|c|}
\hline Biochemical identification tube for lactic acid bacteriao & Y-A-2 \\
\hline Seven leaf glycoside & - \\
\hline Fiber two sugar & + \\
\hline Malt dust & - \\
\hline Mannitol & - \\
\hline Salicin & + \\
\hline sorbitol & - \\
\hline saccharose & - \\
\hline gossypose & - \\
\hline synanthrin & + \\
\hline milk sugar & - \\
\hline 1\% sodium mauric acid & - \\
\hline
\end{tabular}

\section{S rRNA Sequence Analysis}

The general primers for PCR amplification of 16S rRNA gene fragment were designed. Jilin kumei Biotechnology Co., Ltd. was entrusted to synthesize the primers and detect the sequences, and blast was used for sequence comparison. The results showed that the isolated strain Y-B-1 had 2330 nucleotide sequences, which were $100 \%$ homologous with pediocus acidilactici strain hxbm 408 16S ribosomal RNA gene, partial sequence ID: mf992210.1, etc. published in GenBank. The specific comparison results are shown in Table-3.

The results showed that the isolated strain YB-1 had 2330 nucleotide sequences, which were $100 \%$ homologous with pediocus acidilactici strain hxbm 408 $16 \mathrm{~S}$ ribosomal RNA gene, partial sequence ID: mf992210.1, etc. published in GenBank. 
Table-3: Comparison of 16SrRNA homology with a variety of pentoses

\begin{tabular}{|c|c|c|c|c|c|c|}
\hline Description & $\begin{array}{l}\text { Max } \\
\text { score }\end{array}$ & $\begin{array}{l}\text { Total } \\
\text { score }\end{array}$ & $\begin{array}{l}\text { Query } \\
\text { cover }\end{array}$ & $\begin{array}{c}\mathbf{E} \\
\text { valoe }\end{array}$ & Ident & Accession \\
\hline $\begin{array}{l}\text { Pediococcus pentosaceus gene for } 16 \text { S ribosomal } \\
\text { RNA, partial sequence, strain: ZZU A22 }\end{array}$ & 2330 & 2330 & $100 \%$ & 0 & $99 \%$ & LC119127.1 \\
\hline $\begin{array}{l}\text { Pediococcus pentosaceus strain ON-81A } 16 \mathrm{~S} \\
\text { ribosomal RNA gene, partial sequence }\end{array}$ & 2330 & 2330 & $100 \%$ & 0 & $99 \%$ & KX527659.1 \\
\hline $\begin{array}{l}\text { Pediococcus pentosaceus gene for } 16 \mathrm{~S} \text { ribosomal } \\
\text { RNA, partial sequence, strain: ZZU } 64\end{array}$ & 2330 & 2330 & $100 \%$ & 0 & $99 \%$ & AB831184.1 \\
\hline $\begin{array}{l}\text { Pediococcus pentosaceus strain wg8 16S } \\
\text { ribosomal RNA gene, partial sequence }\end{array}$ & 2330 & 2330 & $100 \%$ & 0 & $99 \%$ & JX477168.1 \\
\hline $\begin{array}{l}\text { Pediococcus pentosaceus strain MRSF2 16S } \\
\text { ribosomal RNA gene, partial sequence }\end{array}$ & 2330 & 2330 & $100 \%$ & 0 & $99 \%$ & KF048926.1 \\
\hline $\begin{array}{l}\text { Pediococcus pentosaceus strain PP 16S ribosomal } \\
\text { RNA gene, partial sequence }\end{array}$ & 2330 & 2330 & $100 \%$ & 0 & $99 \%$ & HQ286591.1 \\
\hline $\begin{array}{l}\text { Pediococcus pentosaceus gene for } 16 \mathrm{~S} \text { ribosomal } \\
\text { RNA, partial sequence, strain: MJK7 }\end{array}$ & 2330 & 2330 & $100 \%$ & 0 & $99 \%$ & AB494722.1 \\
\hline $\begin{array}{l}\text { Pediococcus pentosaceus strain CAU85 16S } \\
\text { ribosomal RNA gene, partial sequence }\end{array}$ & 2330 & 2330 & $100 \%$ & 0 & $99 \%$ & MF424141.1 \\
\hline $\begin{array}{l}\text { Pediococcus pentosaceus strain SP-024 16S } \\
\text { ribosomal RNA gene, partial sequence }\end{array}$ & 2330 & 2330 & $100 \%$ & 0 & $99 \%$ & KX527660.1 \\
\hline $\begin{array}{l}\text { Pediococcus pentosaceus strain ON-89A } 16 \mathrm{~S} \\
\text { ribosomal RNA gene, partial sequence }\end{array}$ & 2330 & 2330 & $100 \%$ & 0 & $99 \%$ & KX387352.1 \\
\hline $\begin{array}{l}\text { Pediococcus pentosaceus strain SNR-1 16S } \\
\text { ribosomal RNA gene, partial sequence }\end{array}$ & 2330 & 2330 & $100 \%$ & 0 & $99 \%$ & KU728709.1 \\
\hline $\begin{array}{l}\text { Pediococcus pentosaceus strain ZTR-2 16S } \\
\text { ribosomal RNA gene, partial sequence }\end{array}$ & 2330 & 2330 & $100 \%$ & 0 & $99 \%$ & KU728706.1 \\
\hline
\end{tabular}

\section{Analysis of Strain Growth Characteristics Determination of Optimum Growth Temperature of the Strain}

The activated lactobacillus was inoculated to the inoculation dose at $2 \%$. The activated lactobacillus pentococcus was inoculated to MRS liquid medium at $2 \%$ inoculation dose, and then was cultured at $16^{\circ} \mathrm{C}$, $23^{\circ} \mathrm{C}, 30^{\circ} \mathrm{C}, 37^{\circ} \mathrm{C}, 44^{\circ} \mathrm{C}, 51^{\circ} \mathrm{C}$, and $58^{\circ} \mathrm{C}$, respectively. It can be seen from the respectively. It can be seen from the figure2 that the OD600 value of this strain is relatively low when the temperature is lower than $23^{\circ} \mathrm{C}$ and higher than $37^{\circ} \mathrm{C}$, while the OD600 value is the highest when the temperature is $30^{\circ} \mathrm{C}$, indicating that the strain grows best at $30^{\circ} \mathrm{C}$, grows slowly at other temperatures, and almost stops growing when the temperature is higher than $58^{\circ} \mathrm{C}$.

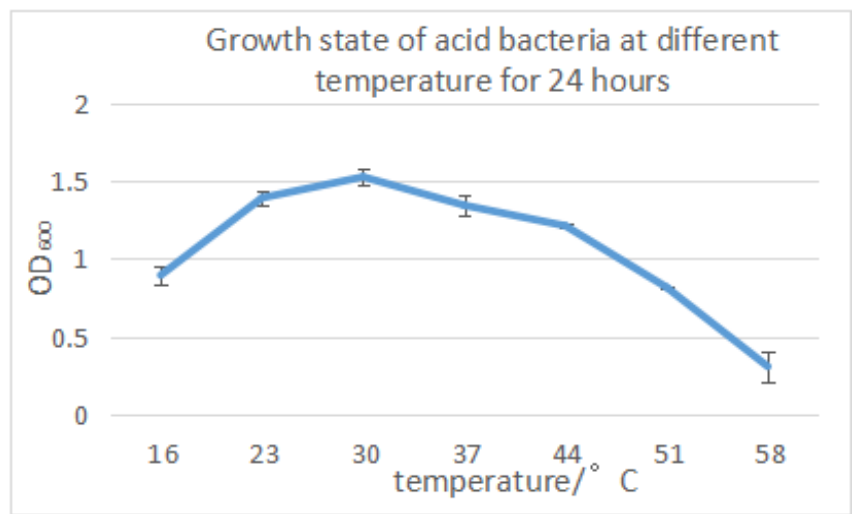

Fig-2: Y-B-1 at different temperatures

\section{Determination of Strain Growth Curve}

With $2 \%$ inoculation amount will activate the amount of lactic acid bacteria to inoculated will activate pediococcus pentosaceus to $2 \%$ inoculation amount to MRS liquid medium, at $30^{\circ} \mathrm{C}$ under the condition of anaerobic culture for $24 \mathrm{~h}$, take a sample a defective goods every $2 \mathrm{~h}$, shake to determine microbial OD600 value, draw the growth curve of lactic acid bacteria after $24 \mathrm{~h}$, the result is visible as the extension of time strain concentration was gradually rising trend, and strains belong to the logarithmic phase, after $16 \mathrm{~h}$ almost close to a plateau, the strain growth characteristics and conventional bacterial growth trend, the specific results as shown in Figure-3.

\section{Y-B-1 24h growth curve}

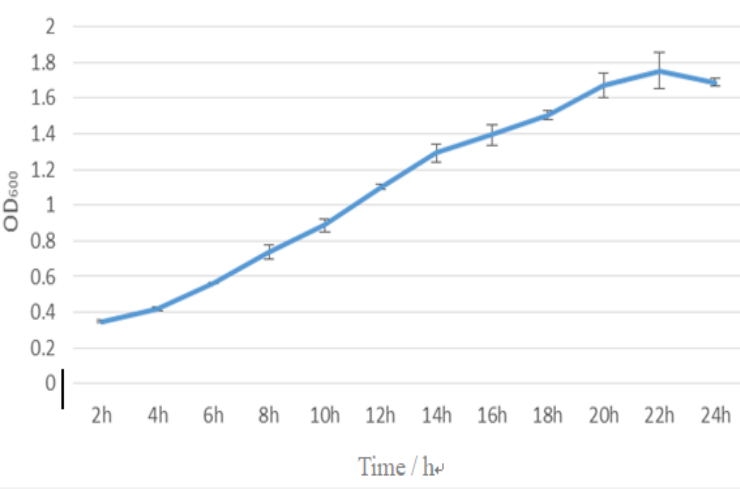

Fig-3: Y-B-1 24h growth curve 


\section{Determination of acid resistance of the strain}

With 2\% quantity of activation of four strains of lactic acid bacteria inoculated to initial inoculation amount will activate pediococcus pentosaceus to $2 \%$ inoculation amount to the initial $\mathrm{pH} \mathrm{pH}$ 1.5, respectively, $\mathrm{pH} 3.5, \mathrm{pH} 5.5, \mathrm{pH} 7.5, \mathrm{pH} 9.5, \mathrm{pH} 11.5$ MRS liquid medium, at $30^{\circ} \mathrm{C}$ under the condition of anaerobic culture, $24 \mathrm{~h}$ after the shake sampling determination of different $\mathrm{pH}$ gas-bacilli OD600 value, and draw curves as shown in figure 5, the figure shown strains $\mathrm{pH}$ less than 3.5 or $\mathrm{pH}$ greater than 9.5 within the scope of almost stopped growing, It grows very well in the pH5.5 to 7.5 range.

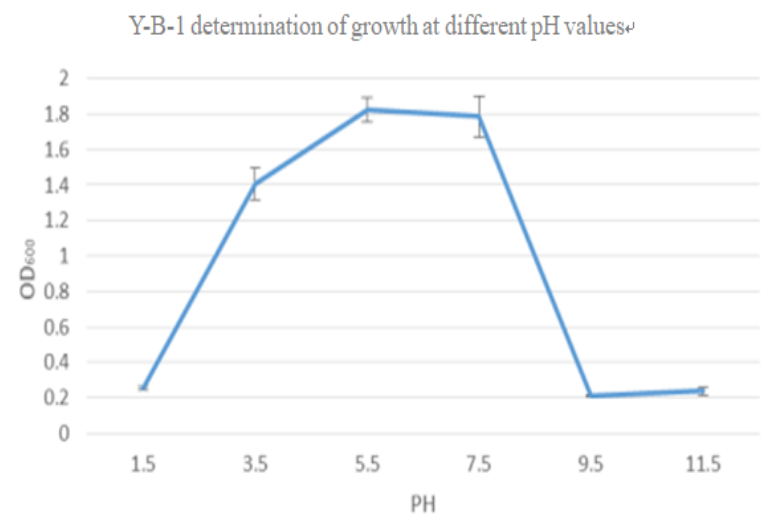

Fig-4: Y-B-1 determination of growth at different $\mathrm{pH}$ values

\section{Determination of Salt Tolerance of the Strain}

With 2\% quantity of activation of four strains of lactic acid bacteria inoculated to initial inoculation content will activate pediococcus pentosaceus to $2 \%$ inoculation amount to initial to contain containing $\mathrm{NaCl}$ was $1.5 \%, 3.5 \%, 5.5 \%, 7.5 \%, 9.5 \%, 11.5 \% \mathrm{NaCl}$ MRS liquid medium, in $30^{\circ} \mathrm{C}$ under the condition of anaerobic culture, $24 \mathrm{~h}$ after the shake sampling determination of different $\mathrm{pH}$ gas-bacilli OD600 value, and draw curves as shown in figure 5, the figure shown strain can grow well under salt ion concentration is 7.5, and the salt ion is higher than 9.5 under the environment of almost stops growing.

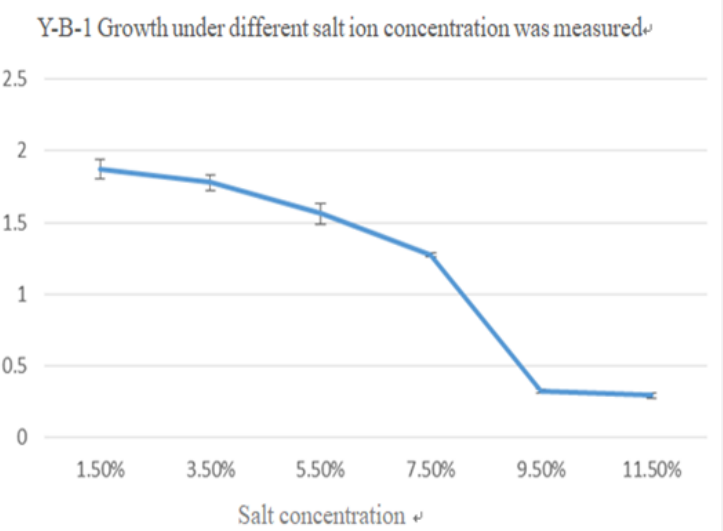

Fig-5: Y-B-1 Growth under different salt ion concentration was measured

\section{DISCUSSION}

In order for lactic acid bacteria to play a stable physiological and biochemical role in the intestine, they must enter the stomach and intestines and maintain good activity in an environment containing a variety of enzymes and low $\mathrm{pH}$ values. Microorganisms in the animal digestive tract have specificity and diversity, and there is a close relationship between animals and various intestinal microorganisms as well as a variety of microorganisms that are mutually utilized, selected and interdependent [8]. This experiment was isolated from adult bovine rumen Y-B-1 plant aureus pediococcus pentosaceus, derived from adult bovine rumen, derived from the digestive tract, non-toxic side effects, resistance to acid enzymatic resistance is strong, can grow in the stability of the bovine rumen, easier to play a role of engraftment live from animal intestine, help probiotic feed additives and animal husbandry research [9].

In this study, Y-B-1 strain isolated from the rumen of adult cattle was identified by morphological analysis of bacteria, physiological and biochemical characteristics detection, and homology analysis of 16SrRNA sequence. The results showed that Y-Blbiological activities such as fermentation maltose, lactose and inulin.

After the rumen contents reached a relatively stable state, the temperature was about $38-41^{\circ} \mathrm{C}$. Influenced by the type of feed and the temperature of drinking water, it affects the digestion of feed food. But we separated strains grow best under $30^{\circ} \mathrm{C}$ temperature, instructions will be in the rumen bacteria isolated and alone in the case of many bacteria interactions of different shape instructions will be in the rumen bacteria isolated and alone in the case of many bacteria interactions of characters are different. The $\mathrm{pH}$ value of rumen contents was determined by volatile fatty acids in bovine rumen chyme, buffer salts in saliva and rumen epithelium to volatile fatty acids. Generally, the $\mathrm{pH}$ value ranges from 6 to 7 . The strains isolated in this study all grew well in the range of $\mathrm{pH} 5.5$ to $\mathrm{pH} 7.5$, which was basically similar to the $\mathrm{pH}$ in the rumen environment and consistent with the growth characteristics of the bacteria in the rumen.

\section{REFERENCE}

1. Guo D, Hao Y. Measures to improve feed digestibility of dairy cattle $[\mathrm{J}]$. Breeding technical consultant. 2014, (5):61.

2. $\mathrm{Hu} \mathrm{H}, \mathrm{Su}$ SF, Liu YZ, Liu HK, Wang YH. Identification of a Staphylococcus epidermidis Isolated from Rumen and the Cloning of $\beta$ glucanase Gene and Its Expression in Lactococcus lactis. Animal Husbandry and Feed Science. 2013(5):1-6.

3. Lu Y, Zhou, L, Zhao, S. Research progress of rumen microorganism isolation and culture in recent 10 years $[\mathrm{J}]$. Chinese Journal of 
microbiology 2012, (9): 856-861.

4. Yang $C$, Yang B, Liang $\mathrm{X}$. New progress of buffalo nutrition research $[\mathrm{J}]$. China animal husbandry and veterinary .2013, (12): 85-89.

5. Ma C, Zhang H, Liu C. Progress in microbial diversity in rumen and gut of cattle $[\mathrm{J}]$. Journal of animal nutrition 2014, (4): 852-862.

6. Goldstein EJ, Tyrrell KL, Citron DM. Lactobacillus species: taxonomic complexity and controversial susceptibilities. Clin Infect Dis, 2015, 60(2):S98.

7. Cousin FJ, Lynch SM, Harris HM, McCann A, Lynch DB, Neville BA, Irisawa T, Okada S, Endo A, O'Toole PW. Detection and genomic characterization of motility in Lactobacillus curvatus: confirmation of motility in a species outside the Lactobacillus salivarius clade. Appl. Environ. Microbiol.. 2015 Feb 15;81(4):1297-308.

8. Yakovlieva M, Tacheva T, Mihaylova S, Tropcheva R, Trifonova K, Toleкоva A, Danova $\mathrm{S}$, Vlaykova T. Influence of Lactobacillus brevis 15 and Lactobacillus plantarum 13 on blood glucose and body weight in rats after high-fructose diet. Beneficial microbes. 2015 Aug;6(4):505-12.

9. Song BF, Ju LZ, Li YJ, Tang LJ. Chromosomal insertions in the Lactobacillus casei upp gene that are useful for vaccine expression. Appl. Environ. Microbiol.. 2014 Jun 1;80(11):3321-3326. 